\title{
ISLAMIC BANKING EFFICIENCY AND INCLUSIVE SUSTAINABLE GROWTH: THE ROLE OF FINANCIAL INCLUSION
}

\author{
Hasanul Banna ${ }^{1}$ and Md Rabiul Alam² \\ ${ }^{1}$ UACDS, FEA, University of Malaya, Malaysia, banna@um.edu.my \\ ${ }^{2}$ University of Malaya, Malaysia, rabiulalam_84@yahoo.com
}

\begin{abstract}
This paper aims to estimate the efficiency scores of 153 Islamic banks of 32 countries during the period 2011 to 2017 by deploying data envelopment analysis and SimarWilson double bootstrapping regression techniques to determine how financial inclusion and its interaction effect with GDP growth impact on Islamic banking efficiency to promote inclusive sustainable growth. The findings show that the efficiency trends of Islamic banks in most countries have been inconsistent in the aftermath of the global financial crisis; this indicates that the banking industry is still bearing the consequences of that recession. However, Islamic banks in Bangladesh, Malaysia, Mauritia, Qatar, Tunisia, and Sudan are performing efficiently and, in spite of being war-affected countries, Islamic banks in Iraq and Palestine, more interestingly, have also seen an ascending trend in terms of improving their efficiency levels. The results foreground that to improve Islamic banks' efficiency, financial inclusion (FI) must play a key role. Moreover, the effect of the interaction between FI and GDP growth suggests that FI plays a significant role in sustainable development, which creates a positive relationship between inclusive sustainable growth and the efficiency of Islamic banks. Since research on FI is an ongoing process, this paper contributes to the existing literature and methodology pertinent to the subject by analysing both non-bias and bias-corrected efficiency through the utilisation of more recent data from Islamic banks.
\end{abstract}

Keywords : Financial inclusion, Bias-corrected efficiency, Inclusive sustainable growth, Islamic banks, Global financial crisis.

JEL Classification: C34; C38; G01; G21.

\author{
Article history: \\ Received : September 27, 2019 \\ Revised : January 13, 2020' \\ Accepted : January 28, 2020 \\ Available online : February 28, 2020
}

https://doi.org/10.21098/jimf.v6i1.1089 


\section{INTRODUCTION}

\subsection{Background}

Whether financial inclusion (FI), an overtly discussed issue in the arena of finance and economics, brings Islamic banking efficiency or not is a matter of great concern to scholars around the world and has been a continual issue explored by research. The research on the role of FI has been more visible since the Global Financial Crisis (GFC) of 2007-2009. The impact of the GFC was so destructive that it caused the collapse of conventional banking (Banna et al., 2020) and the world is still suffering its consequences and attempting to surmount it. The GFC made scholars ponder alternative solutions to overcome the post-crisis period. Thus, Islamic finance, which is practised by Islamic banks, was appreciated as an alternative solution because, due to its integral stability, Islamic finance has the power to overcome any shocks (Mirakhor, 2008).

Therefore, along with other financial institutions, and the banking sector in particular, the Islamic banking sector has been relentlessly working to formulate innovative plans that are attractive to clients in order to retain them during this crucial period. As well as many other services and innovative plans, this banking sector focuses more on FI, which has been unquestionably accepted by scholars, stakeholders, researchers and financial organisations during recent years (Kim et al., 2018). Financial inclusion means rendering easily reachable client-friendly services, such as ATM booths, SMS service, free accounts for students, house loans, car loans, opening more bank branches in rural areas, mobile banking, cashless service, credit cards, SME loan facilities, short-term and long-term deposit schemes, and so on (Jahan et al., 2019).

The major characteristics of the Islamic banking system are zero tolerance of interest in any kind of transaction: no financial aid to illegal, anti-social, unethical and unlawful business sectors, such as gambling, alcohol, or the pornography industry (Abdul-Majid et al., 2010). These bring more thrift and place this banking sector, from many respects, in a better position compared to conventional banking (Sole, 2007). With a view to accelerating this flow of thrift, nowadays, FI is seen to be vibrant in the Islamic banking sector and in Islamic countries (Mohieldin et al., 2011) because it also helps increase banking efficiency, which, in turn, contributes to inclusive sustainable growth. Thus, Islamic banks, considered as one of the greatest contributors to the overall economy of the world (Sole, 2007), are in the process of introducing various types of easily reachable and affordable services for customers in the form of FI. This contributes to both their financial stability and efficiency, and to the inclusive sustainable development of society.

\subsection{Objective}

A few studies have been carried out by world-renowned scholars (e.g. Ahamed \& Mallick, 2019; Owen \& Pereira, 2018) dealing with the efficiency, FI and economic stability of the conventional banking sector, but studies germane to the Islamic banking industry have been very rare compared to those related to conventional banking. After the GFC, scholars were very curious to reveal the magical story of the successful journey of Islamic banks and research and since that time, research has been undertaken at pace. However, very few studies (e.g. Banna et al., 2020; 
Kim et al., 2018) have been carried out to show the impact of FI on Islamic banks, which, in turn, promote inclusive economic growth.

Thus, the objective of this paper is to fill the gap by estimating Islamic banking efficiency and investigating how FI and its interaction with GDP growth affect the efficiency of Islamic banks, which subsequently leads to the attainment of inclusive sustainable growth. Islamic banks currently operate in more than 50 countries throughout the world (Rosman et al., 2014). However, we have analysed Islamic banks based on the availability of data in the Orbis BankFocus (formerly known as BankScope) database to estimate the actual performance of their smooth financial activities in the aftermath of the GFC.

This study adds value to the prevailing literature and methodology in a number of ways. First, the study measures the non-bias and bias-corrected efficiency of Islamic banks of 32 countries during the period 2011-2017 using the most recent available data to see the efficiency trend of Islamic banks in the aftermath of the GFC, unlike previous studies. Second, it intends to investigate the relationship between FI and the efficiency of Islamic banks as this association helps to determine how FI plays a vital role in the advancement of the efficiency of the Islamic banking sector. Third, the association between Islamic banking efficiency and the interaction effect of FI with GDP supports our understanding in relation to how the Islamic banking sector can attain inclusive sustainable growth through innovative financial services. Finally, this study extends the data envelopment analysis (DEA) and the double bootstrapping regression techniques of Simar and Wilson (2007) in the Islamic banking sector to estimate bias-corrected efficiency and its determinants. These methods have been deployed in this study because the ordinary least squares (OLS) method, the generalised method of moments (GMM), the Tobit regression model, and others have been acutely condemned by existing studies (Daraio et al., 2018; Simar \& Wilson, 2011) due to their biased estimation and misspecification during the second stage analysis.

The remainder of the paper is structured as follows. An account of the literature review is drawn in Section two. Section three contains a detailed discussion of the methodology used. Section four depicts the findings of the study and their discussions, while Section five gives an overview of the concluding remarks along with policy implications and suggestions for future studies.

\section{LITERATURE REVIEW}

\subsection{Background Theory}

Inclusive finance, which has more access to financial instruments and an extensive financial sector outreach, is visibly capable of reducing agency problems and information asymmetries between creditors and debtors (Beck et al., 2014). Such inclusive finance is also capable of decreasing the volatility of the funding of banks by collecting deposits from a vast clientele base (Han \& Melecky, 2013) and reduce the volatility of return because banks do not depend more on costly and risky money market funds (Kacperczyk \& Schnabl, 2013). On the contrary, inclusive finance increases agency problems because of the structure of the organisation and its large product mix and decreases a bank's operating efficiency when it becomes problematic for the bank's headquarters to monitor the activities of branches that 
are located in distant places (Brickley et al., 2003). Thus, studies from both sides show that banking efficiency can be augmented or reduced by inclusive finance. However, if the overall benefits related to inclusive finance become more than the costs, a positive association between inclusive finance and banking efficiency is then evident.

When banks become more efficient in any country, their overall economic growth is accelerated (Banna et al., 2020). Economic growth is considered to be the key driver of sustainable development. In this regard, many innovative and time-demanding ideas have been launched in which FI is a part of those ideas and is deemed to be a leading driver of inclusive growth. In recent years, FI gained attention from scholars; studies show that FI has a positive relationship with economic growth and financial exclusion and poverty (Kim et al., 2018). FI means that formal financial services are reachable by all people in a country regardless of their economic status, gender, race or living standards. It mainly focuses on economically deprived and disadvantaged people to be brought under the umbrella of formal financial services with an affordable and minimal cost (World Bank Group, 2013).

Formal financial services refer to having a formal account in a bank or other financial institutions so that clients can deposit, save or make money transactions (Demirgüç-Kunt et al., 2018). Availing these services summons stability within society. However, societies in which people have to struggle to avail formal financial services face many types of financial problems (Kim et al., 2018). According to the World Bank Group (2013), half of the world's population do not have access to formal financial services; this is one of the great hindrances to financial stability and it results in poverty. When people are aware of financial services, they come to know how to deposit and save money for moments of crisis. Financial awareness and proper FI is a process in which the quantity, quality, transparency and efficiency of financial services are ensured and can lead society towards being financially stable, help improve overall living standards and reduce poverty (Le et al., 2019).

Well-accepted financial services are the rotating wheel of a sustainable economy. Inclusive development refers to the impartial and unbiased management of wealth among all people, irrespective of their caste, race, sex, religion or living standards. This way, efficiency can be achieved. According to Galor and Moav (2004), the availability of finance to productive business sectors helps to improve efficiency by reducing credit constraints. The study introduces a financial inclusion parameter based on Jeong and Townsend (2007), which considers the fraction of individuals in terms of their access to financial markets.

\subsection{Previous Studies}

In this study, financial inclusion refers to formal financial services, such as bank accounts, bank deposits, loans, credits, and insurance, which can be accessed by all participants living within an economy. By using these sorts of formal financial services, participants or clients benefit and are economically stable; this, in turn, reduces poverty and ensures harmony among the people. 
This is why banks all over the world are launching various types of formal financial services for their clients in a competitive manner. Taking panel data from 55 Organization of Islamic Cooperation (OIC) countries, Kim et al. (2018) state that, within the concept of globalisation, FI has been deeply contemplated because banking efficiency is usually measured according to its financial services. Ahamed and Mallick (2019) state that FI has a positive impact on banking efficiency. This means that banks that render more formal financial services conducive to the clients strengthen their financial efficiency. To provide financial services to customers, there needs to be a good rapport between banks and their clients. Good relationships with all customers enhances the market demand of the banking sector, and a high level of market demand allows banks to provide more loans to poor businessmen (Di Patti \& Dell'Ariccia, 2001). Services to more clients prevent a reliance on big and wholesale funding for their own existence and survival (Demirgüç-Kunt \& Huizinga, 2010). To make their services reachable to people of all classes, banks can expand their branches throughout the country; this helps with poverty alleviation. Analysing the contexts of India (Burgess \& Pande, 2005) and Mexico (Bruhn \& Love, 2014) show that more bank branches at a village level and reachable financial services play a vital role in poverty eradication and hunger reduction (Owen \& Pereira, 2018). According to Hannig and Jansen (2010), by being on good terms with clients, banks can lessen information asymmetry, and by providing low-cost, easily accessible and innovative financial services, they also become capable of reducing marginal production costs. Greater access to financial services enhances the efficiency level of the banking industry and brings advancement for both bank stability and social stability. In particular, greater opportunities to use financial services helps to create new firms (Banerjee et al., 2015); enhances employment sectors (Prasad, 2010); and assists in the eradication of poverty and income inequality (Bruhn \& Love, 2014).

Studies on banking efficiency and financial inclusion are limited. However, a small number of previous studies show the relationship between FI and banking stability. For example, the study by Ahamed and Mallick (2019) indicates that there is a significant positive association between FI and financial stability. Based on their empirical study through the employment of micro-level data, Ahamed and Mallick (2019) state that those banks that ensured a higher level of FI by providing various types of banking services to customers with a very marginal and low service charge have significant bank stability and financial sustainability. Iqbal and Llewellyn (2002) state that the global financial sector flourishes with the introduction of things like innovative financial products and individual risksharing features for all types of businesses seen in Islamic banking system. Kim et al. (2018) show that FI leads to financial growth and that they are very intrinsically linked. Unlike others, Islamic finance has a significantly positive influence on financial stability. In their study, Rashid et al. (2017) find that, compared to conventional banks, the Islamic banking industry contributes to the establishment of financial sustainability. By using macro-level data taken from the period 20062017 in the context of Jordan, Al-Smadi (2018) finds a very significant positive relationship between FI and inclusive financial growth as it is stated that more FI generates more economic stability within society. In their study, which takes data from richer countries, Dienillah et al. (2018) show that financial inclusion brings financial sustainability for higher-, middle- and lower-income countries. 
Although very few studies have focused on the association between inclusive finance and bank efficiency, an empirical study by Ahamed et al. (2018) provides evidence of this. In their study, they take the data of 2,207 banks across the world during the period 2004-2015 and point out the positive association between FI and banking efficiency. Their study demonstrates that the positive association of these two variables is much stronger in countries where banks can operate with limited restrictions, where foreign banks can enter and run their activities without hindrances, where there is more capital regulation stringency, and where corporate governance is strong through the market-based monitoring of banks. Their study also finds that through a higher level of FI, banks can rebate return volatility and the volatility of customer deposit funding shares. Moreover, they show that compared to banks in developed countries, banks in less developed countries benefit more from inclusive finance, which subsequently helps them to promote bank efficiency.

Hence, the prevailing studies show that FI is positively associated with bank stability and efficiency, which, in turn, leads to financial sustainability within society. Although it is an ongoing research issue, as determined in the literature, very few studies are found with this connection, in particular studies that deal with the FI of Islamic banks with banking efficiency, which, consequently, supports the attainment of inclusive sustainable growth. This might be the cause of Muslim countries' reluctance to move towards formal financial services. The qualitative study by Zulkhibri (2016), which used samples from Muslim countries, shows that in the Muslim countries used in his study, only $27 \%$ of adults aged over 15 years have an account in a formal financial institution. So, how can they come under the umbrella of FI if they do not have a formal bank account? This is the basic requirement when obtaining financial services. Thus, the current study fills the gap in the literature by highlighting the relationship between FI and the efficiency of Islamic banks as well as the effect of the interaction between FI and GDP to attain inclusive sustainable growth.

\section{METHODOLOGY}

This study focuses on how FI drives Islamic banking efficiency and how the interaction of FI and GDP growth helps to achieve inclusive sustainable growth. Therefore, this section presents the DEA and Simar-Wilson (2007) double bootstrapping techniques to determine the relationship between Islamic banks' efficiency and FI and the interaction between FI and GDP growth with bank efficiency. The Simar-Wilson (2007) double bootstrapping technique has been considered in this study because it assists with the control of problems caused by both the endogeneity of the outreach measure related to the efficiency score and the autocorrelation of non-observable components of efficiency compared to other methods such as Tobit, OLS, and panel regression (Banna et al., 2019b). This method provides bias-corrected efficiency scores that attempt the regression using bootstrapped truncated regression in the second stage to fix the measurement error in the technical efficiency scores. 


\subsection{Data}

Initially, this study considers the annual data of 223 Islamic banks from countries that offer Islamic banking services; however, due to data unavailability and missing values, we finally obtained the annual data from 153 Islamic banks of 32 countries during the period 2011 to 2017, yielding 1,078 bank-year observations. We consider multiple countries as we assume that the nature of operational activities of Islamic banks is similar; the major characteristics of this banking system are zero tolerance of any interest in any kind of transaction, no financial aid to illegal, anti-social, unethical and unlawful business sectors, such as gambling, alcohol, and the pornography industry (Abdul-Majid et al., 2010), which are applicable to all countries. This research is limited in that it does not consider data from conventional banks. This is because the purpose of this study is to see the impact of FI on Islamic bank efficiency and its role on inclusive sustainable growth. For this study, bank-specific variable data have been collected from the Orbis BankFocus database, the most authentic source of stored banking data in the world (Banna et al., 2017). The Financial Access Survey (FAS) of the International Monetary Fund (IMF) and the World Development Indicators (WDI) of the World Bank provide the FI and macro-economic data, respectively. Banks that have had missing data in the database for many years have been excluded. Banks' annual reports have been considered to find the data of those banks who have missing data. Because we failed to recover it, we have measured the missing data by working out an average for cases in which data is missing for only one year. Following Banna et al. (2018), the 1st and 99th percentiles of the variables are winsorised for the analysis.

\subsection{Model Development}

In the literature, parametric and non-parametric approaches are widely used to measure efficiency. This study uses a mere non-parametric DEA approach to estimate the efficiency of Islamic banks. In brief, Charnes et al. (1978) initiated the DEA, a non-parametric linear programming method (Farrell, 1957), to analyse the relative efficiency of a set of comparable decision-making units (DMUs) with a number of inputs and outputs. Later, Banker et al. (1984) modified the first DEA model to estimate efficiency under a variable returns to scale (VRS) assumption. We choose the DEA over the stochastic frontier approach (SFA) for two key reasons. First, the DEA does not need to provide a pre-specified production function (Gardener et al., 2011). Thus, the DEA needs fewer econometric specifications and is more user-friendly than the SFA. Second, it neither entails many assumptions about the technology nor imposes any restrictive hypotheses. Therefore, it is also suitable for a small sample size. Following Gardener et al. (2011), we use the VRS input-oriented (cost minimisation) model to measure the efficiency of Islamic banks. The input-oriented DEA approach is used as it sorts technical efficiency as a relative deterioration in the usage of the input and to calculate technical efficiency as a relative growth in the output. The choice of VRS over constant returns to scale (CRS) is suitable because the operation of all of the banks is not at an optimum scale due to financial constraints and imperfect competition (Banna et al., 2019a).

The mathematical specification of the DEA-VRS input-oriented model is as follows: 
$\operatorname{Min} \theta$

Such that:

$$
\begin{gathered}
\sum_{j=1}^{n} \varphi_{j} B_{q j} \geq B_{q 0} ; q=1,2, \ldots . . y \\
\sum_{j=1}^{n} \varphi_{j} A_{i j} \leq \theta A_{i 0} ; i=1,2, \ldots . . x \\
\varphi_{j} \geq 0 ; j \in 1,2 \ldots m \\
\sum_{j=1}^{n} \varphi_{j}=1
\end{gathered}
$$

where, $\theta$ refers to the technical efficiency score, $B_{q j}$ and $A_{i j}$ are shown as the value of the $q$ th output generated and the value of the ith input consumed by the $j$ th bank, respectively. The $m$ index refers to the bank observations' number, $x$ refers to input(s), $\mathrm{y}$ indicates output(s) and $\varphi$ is constant. The first two constraints restrict the data from being enveloped in both the upper and lower. The third constraint is required to be non-negative in relation to all inputs and outputs. The use of VRS is allowed by the fourth constraint.

However, the conventional method of estimating the efficiency score and identifying the determinants of efficiency at a second stage has a severe flaw; DEA efficiency scores are consecutively interrelated with an additional source of endogeneity, which is the result of the measurement error in the efficiency estimates (Daraio et al., 2018; Simar \& Wilson, 2011). Hence, the double bootstrapping method by Simar-Wilson (2007) is considered during the second stage analysis to explore the key determining factors of the technical efficiency of Islamic banks and, in particular, how FI helps achieve inclusive sustainable growth by improving the efficiency of this banking sector.

Simar-Wilson (2007) ${ }^{1}$ recommend two bootstrap techniques for the estimation problem related to two-stage efficiency. The primary step is intended to improve on inference, but does not consider the bias-corrected estimation of efficiency, called Algorithm 1. In the first-stage problem, a parametric bootstrap has been deployed to have bias-corrected estimates, called Algorithm 2. Algorithm 2 functions in two stages. During the first stage, a bias-corrected estimation related to the Shepard's distance function is estimated and from the original distance function estimate, the bootstrap bias estimate is subtracted. This approach assists in restricting the problems caused by both the endogeneity of outreach measures related to the efficiency score and autocorrelation of the non-observable efficiency components (Banna et al., 2019b). These bias-corrected efficiency scores attempt regression using bootstrapped truncated regression during the second stage. This

1 The details can be found in Simar and Wilson (2007). 
method refers to the serial correlation in the DEA efficiency estimates and fixes the measurement error in technical efficiency scores used to examine the determining factors of technical efficiency. The 'Simarwilson's' command in Stata is used to operationalise the first and second steps of Algorithm 2.

\section{Input-output variables selection technique}

Although no exact theory or clear specifications have been identified for banks to determine input-output variables, Berger and Humphrey (1997) suggest that the production approach compares the efficiency of different branches of the same bank and the intermediation approach assesses all financial institutions. Banks provide intermediary services between the demand and supply of funds (Rosman et al., 2014). More specifically, Islamic banks provide intermediation services by collecting deposits and other funds that are, in turn, invested in productive sectors, which give profit that is free from usury (riba). Because the purpose of this study is to compare all financial institutions rather than different branches of the same bank, we consider an intermediation approach to select input-output variables.

Accordingly, three inputs: short-term funding, deposits and staff expenses, and fixed assets; and two outputs: other earning assets and loans, are considered to measure Islamic banking efficiency.

\subsection{Method}

To find the association between FI and Islamic banking efficiency and the interaction effect of FI and GDP growth on Islamic bank efficiency, the subsequent baseline equation is specified.

$$
\begin{gathered}
\theta_{i j t}=\gamma_{0}+\gamma_{1} S I Z E_{i j t}+\gamma_{2} C A P_{i j t}+\gamma_{3} R O A A_{i j t}+\gamma_{4} C R_{i j t}+\gamma_{5} G D P_{j t}+\gamma_{6} I N F_{j t} \\
+\gamma_{7} F I_{j t}+\gamma_{8}(F I x G D P)_{j t}+\varepsilon_{i j t}
\end{gathered}
$$

where,
$\theta_{i j t} \quad=$ DEA efficiency score of the bank $i$ of country $j$ in year $t$;
$S I Z E_{i j t} \quad=$ The natural logarithm of total assets of the bank $i$ of country $j$ in year $t$;
$C A P_{i j t}=$ Total equity/total assets (capitalisation) ratio of the bank $i$ of country $j$ in year $t$;
$R O A A_{i j t} \quad=$ Return on Average Assets of the bank $i$ of country $j$ in year $t ;$
$C R_{i j t} \quad=$ Loan loss prov./ net int. revenue (credit risk) of the bank $i$ of country $j$ in year $t$;
$G D P_{j t} \quad=$ Gross domestic product (GDP) growth of the country $i$ and in year $t ;$
$I N F_{j t} \quad=$ Inflation rate of country $j$ in year $t$;
$F_{j t}{ }^{j t} \quad=$ Financial inclusion of country $j$ in year $t$;
$(F I x G D P)_{\mathrm{jt}}=$ Interaction between financial inclusion and GDP growth of country $j$ in year $t$;
$\varepsilon_{i j t} \quad=$ Error term of the bank $i$ of country $j$ in year $t$.

2 Details on the Stata procedure can be found in Badunenko and Tauchmann (2018). 


\section{Financial inclusion proxies}

The main objective of inclusive financial growth is to bring all the participants of society, irrespective of their caste, religion, race, sex or living standards under the umbrella of FI so they all have access to formal financial services. Regulators state that FI has two dimensions: financial outreach and usage. Due to the scarcity of data, for both dimensions, proxies are required. As the distant location of financial institutions is seen as one of the main hindrances of benefiting from financial services, the study has utilised the financial outreach dimension to rationalise the prevalence of the financial sector's outreach regarding physical outlets of banks (Allen et al., 2014).

This study uses both geographic and demographic penetrations as they are considered to be the main penetrations of bank services (Beck et al., 2007). With regard to former penetration, the number of bank branches and ATM services per 1000 square kilometres is considered, while the number of bank branches and ATMs allocated for per 100,000 adults is considered as a part of the latter penetration. The number of bank accounts per 1,000 adults to incorporate the penetration of financial access is also considered as a part of the usage dimension.

Through cross-country data, the outreach and determinants are investigated to identify common trends across the aforesaid indicators (Beck et al., 2007). Therefore, a composite indicator across countries and the combination of many interrelated indicators, can be easily understood and compared by the average person (OECD, 2008). Hence, following Ahamed and Mallick (2019), both the composite index and its related determinates are considered to determine FI in this paper. The components that are used as parts of FI are closely connected. To detect the common variation as a single measure from these interrelated determinants of $\mathrm{FI}$, an index is developed using principal component analysis (PCA). The FI index used PCA to make our results more robust.

\section{RESULTS AND ANALYSIS}

The findings of the analysis of Islamic banks' efficiency are illustrated in this section. The efficiency measurement was carried out using the bias-corrected DEA based on the Simar-Wilson (2007) method. The findings of the relationship between Islamic bank efficiency and FI is explained. The other factors pertinent to Islamic banking efficiency can be elucidated.

\subsection{Results}

\section{Descriptive statistics}

Table 1 refers to the summary of banks' input-output variables for estimating efficiency. On average, the total deposits and short-term funding of Islamic banks is $\$ 5277.185$ million and the total in loans is $\$ 3915.854$ million. The other mean earning assets of the sample banks is $\$ 1289.171$ million. The average values of the fixed assets and staff expenses are $\$ 162.118$ and $\$ 66.207$ million, respectively. 
Table 1.

Descriptive statistics of input-output variables (USD in millions)

\begin{tabular}{lccccc}
\hline Variable & Obs & Mean & Std. Dev. & Min & Max \\
\hline Deposits and short-term funding & 1,078 & 5277.185 & 9015.153 & 5.755 & 48428.26 \\
Fixed assets & 1,078 & 162.118 & 440.787 & 0.015 & 2708.945 \\
Staff expenses & 1,078 & 66.207 & 134.253 & 0.628 & 786.636 \\
Loans & 1,078 & 3915.854 & 6847.284 & 4.856 & 38956.64 \\
Other earning assets & 1,078 & 1289.171 & 2159.513 & 0.73 & 13439.62 \\
\hline
\end{tabular}

The descriptive statistics of bank efficiency, bank size, capitalisation, profitability, credit risk ${ }^{3}$, GDP growth and FI are exhibited in Table 2. The table reports the mean, standard deviation, along with the maximum and minimum value for each variable in the sample. Several observations from this table are worth noting for the DEA scores. First, the efficiency scores for Islamic banks have a mean value of above 0.6 (mean $=0.652$, standard deviation $=0.260)$, indicating a general tendency towards efficiency in Islamic banks. With these values, we infer that, on average, Islamic banks suffer from about 35\% (i.e. 1-0.652) of the inefficiencies during the period of study. Moreover, the mean value of the logarithm of the banks' total assets and standard deviations are 7.58 and 1.74, respectively. Thus, a fairly low cross-country variation is suggested by these results. On average, the sample countries have 44 and 43 ATMs per 1,000 $\mathrm{km}^{2}$ and per 100,000 adults, respectively. The sample countries have 16 and 14 commercial bank branches per 1,000 km² and per 100,000 adults, respectively. On average, the number of bank accounts per 1,000 adults is 1,128. Furthermore, on average, the GDP growth and inflation rates of the sample countries are approximately $3.6 \%$ and $8.8 \%$, respectively. In the appendix, we report the pairwise correlation results between the independent variables used in our analysis.

Table 2.

Descriptive statistics of main variables

\begin{tabular}{lccccc}
\hline Variable & Obs & Mean & $\begin{array}{c}\text { Std. } \\
\text { Dev. }\end{array}$ & Min & Max \\
\hline Efficiency & 1078 & 0.652 & 0.260 & 0.034 & 1 \\
Profitability (Return on average assets) (\%) & 971 & 0.951 & 2.441 & -10.879 & 7.174 \\
Total assets (USD in millions) & 971 & 6733.445 & 11148.03 & 20.216 & 59206.77 \\
Size (log of total assets) & 971 & 7.582 & 1.744 & 3.006 & 10.989 \\
Credit risk (Loan loss prov/Net int rev) (\%) & 655 & 26.206 & 72.799 & -145.825 & 486.228 \\
Capitalisation (Total equity/total assets) (\%) & 971 & 15.907 & 15.956 & -27.179 & 82.275 \\
GDP growth (\%) & 1,078 & 3.558 & 3.956 & -13.621 & 13.396 \\
Inflation rate (\%) & 1,078 & 8.765 & 10.201 & -0.835 & 39.266 \\
\hline
\end{tabular}

3 For both Islamic and conventional banks, the use of net interest revenue was standardised by BankFocus, in which it compares the net profit of Islamic banks from financing. The total of the positive and negative flows of income, which is linked to the profit-loss sharing (PLS) arrangements, has been defined as Islamic banks' net interest revenue (Cihák \& Hesse, 2008). 
Table 2.

Descriptive statistics of main variables (Continued)

\begin{tabular}{lccccc}
\hline Variable & Obs & Mean & $\begin{array}{c}\text { Std. } \\
\text { Dev. }\end{array}$ & Min & Max \\
\hline $\begin{array}{l}\text { Financial Inclusion } \\
\text { ATMs per 100k adults }\end{array}$ & 1,078 & 42.814 & 31.812 & 1.876 & 129.574 \\
Branches of commercial banks per 100k & 1,078 & 14.102 & 8.563 & 1.698 & 31.827 \\
adults & 1,078 & 43.356 & 58.579 & 0.314 & 289.423 \\
ATMs per 1k km2 & 1,078 & 15.546 & 19.593 & 0.257 & 105.083 \\
Branches of commercial banks per 1k km2 & 861 & 1127.557 & 832.88 & 120.39 & 3462.845 \\
Number of Bank account per 1000 adults & & & & & \\
\hline
\end{tabular}

Note: Efficiency - Farrell input-oriented technical efficiency (TE) measure under variable return scale (VRS) using DEA, ATMs - Automated Teller Machines. Source: Orbis bank focus, WDI and FAS.

\section{Islamic banks' efficiency}

Table 3 summarises the year-wise mean efficiency score of Islamic banks. Our study mainly focuses on the post-crisis period. In 2014, the overall technical efficiency score touched the highest point $(67.3 \%)$ while it was lower in 2011 (64.8\%). However, it fell again in 2015 (65.6\%) and was relegated to the lowest score in 2017 (64.7\%). The results indicate that Islamic banks demonstrated an average technical efficiency of $65.2 \%$ during the study period.

Table 3.

Summary statistics of the efficiency scores of Islamic banks

\begin{tabular}{lcccc}
\hline Year & Mean & Std. Dev. & Min & Max \\
\hline 2011 & 0.648 & 0.266 & 0.034 & 1 \\
2012 & 0.653 & 0.260 & 0.062 & 1 \\
2013 & 0.635 & 0.263 & 0.065 & 1 \\
2014 & 0.673 & 0.256 & 0.053 & 1 \\
2015 & 0.656 & 0.248 & 0.038 & 1 \\
2016 & 0.650 & 0.258 & 0.054 & 1 \\
2017 & 0.647 & 0.267 & 0.067 & 1 \\
All years & 0.652 & 0.260 & 0.034 & 1 \\
\hline
\end{tabular}

Figure 1 illustrates the country-wise trends of the efficiency of Islamic banks. Most countries show fluctuating trends in their efficiency. Based on the findings, Egypt has had an upward efficiency trend since 2012. Islamic banks in Bangladesh, Malaysia, Mauritia, Qatar, Tunisia and Sudan are performing more efficiently than others. Interestingly, in terms of efficiency, in spite of having war-affected countries, Islamic banks in Iraq and Palestine are performing well. 

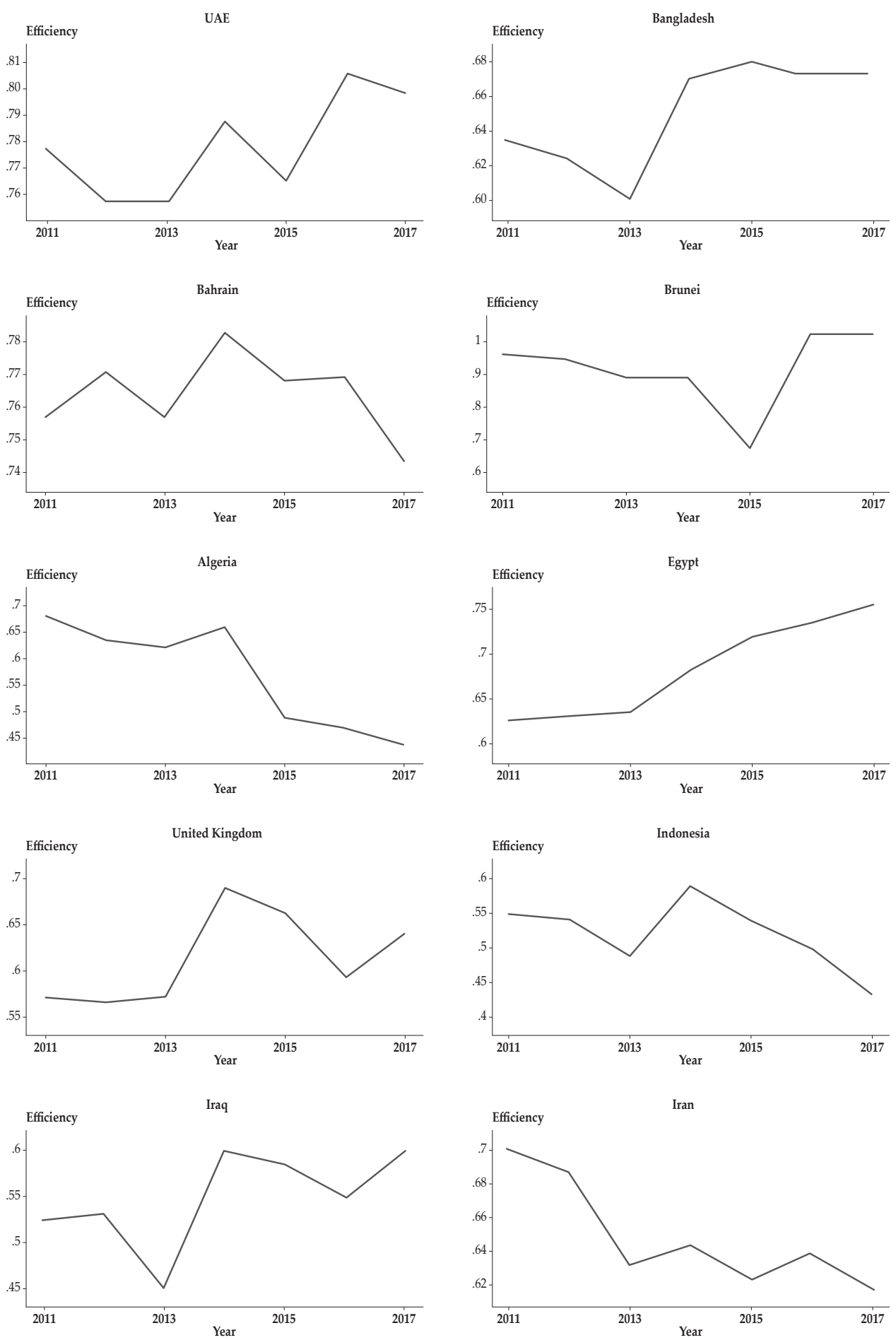

Figure 1.

The country-wise mean efficiency of Islamic banks (2011-2017) 

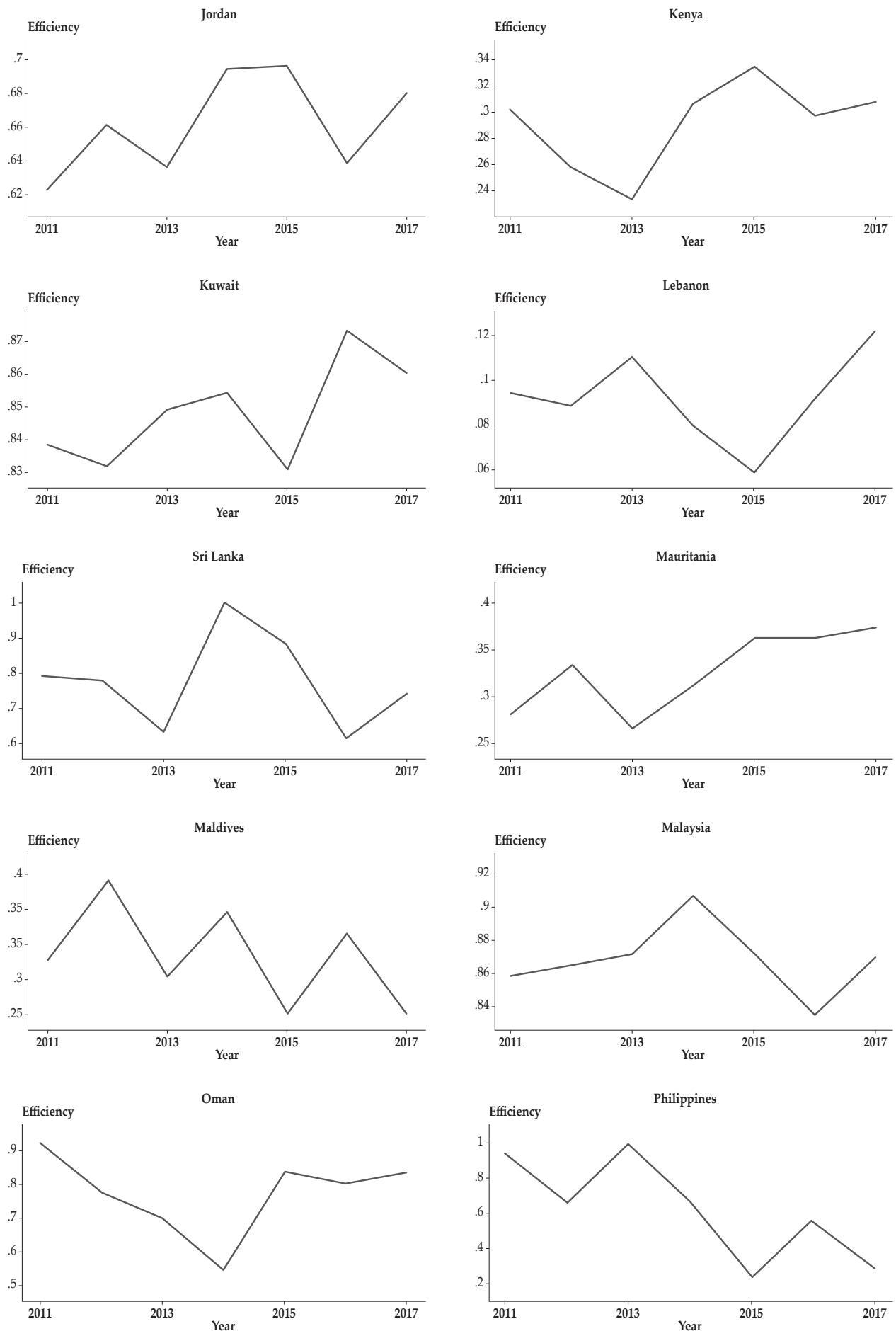

Figure 1.

The country-wise mean efficiency of Islamic banks (2011-2017) (Continued) 

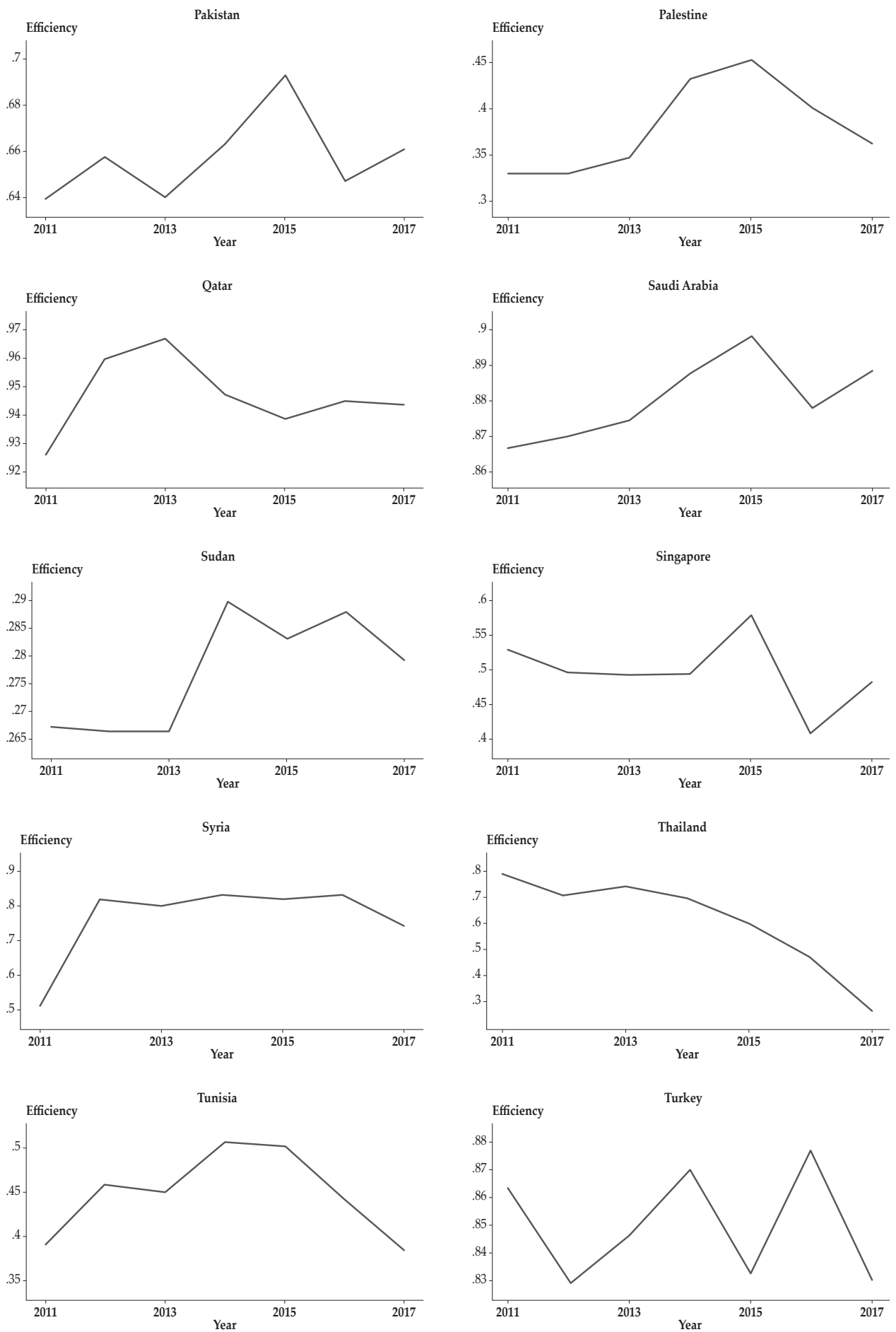

Figure 1.

The country-wise mean efficiency of Islamic banks (2011-2017) (Continued) 

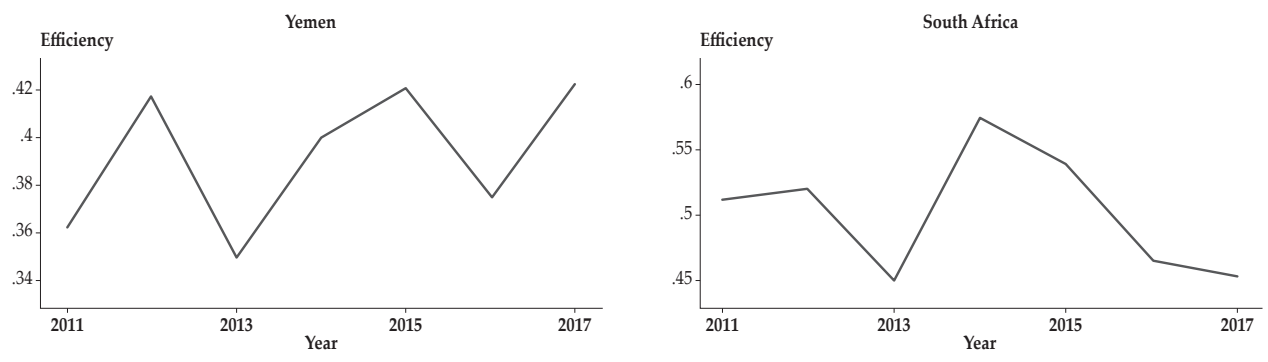

Figure 1.

The country-wise mean efficiency of Islamic banks (2011-2017) (Continued)

As the above efficiency scores are not bias-corrected (as criticised by the scholars), we consider the Simar-Wilson bias-corrected efficiency scores. Figure 2 shows both the non-bias-corrected and bias-corrected efficiency scores of Islamic banks. The findings show that the bias-corrected efficiency scores of Islamic banks (overall efficiency $=0.398$ ) are lower than the non-bias-corrected efficiency scores (overall efficiency $=0.652$ ). The results obtained through this technique suggest that, to produce the same unit of outputs that Islamic banks have already produced, $60.2 \%$ of the inputs could have been saved by banks.

\section{Effeciency VS Simar-wilsom Bias-corrected Efficiency}

Efficiency

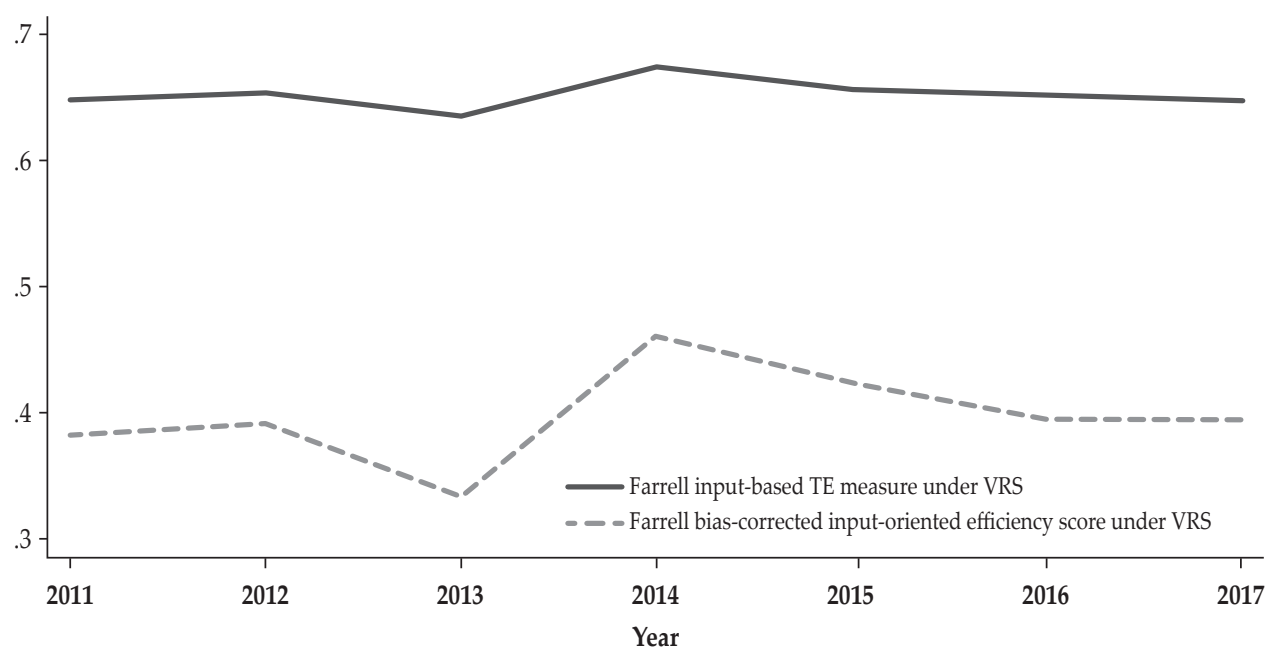

Figure 2.

The efficiency vs bias-corrected efficiency of Islamic banks (2011-2017) 
The financial inclusion, inclusive sustainable growth and efficiency of Islamic banks

To see the association between Islamic banks' efficiency and FI, and the interaction effects of FI and GDP growth on efficiency, we consider the Simar-Wilson (2007) double bootstrapping regression (Algorithm 1 and Algorithm 2) due to the criticisms of the Tobit regression. We control bank-specific factors such as bank size, capitalisation, profitability and credit risk and macro-economic factors such as GDP growth and inflation rates for the analysis.

In our analysis, the FI is divided into two main dimensions: financial outreach of the financial institutions (ATMs and branches) and client usage (number of bank accounts). Financial outreach is classified into two penetrations: demographic and geographic. Models 1-4 show the relationship between Islamic banks' efficiency and FI (financial outreach) in which Models 1 and 2 demonstrate the demographic penetration and Models 3 and 4 display the geographic penetration of financial outreach. Model 5 exhibits the relationship between Islamic banks' efficiency and FI (client usage). The interaction of FI and GDP growth has been considered. This will show how FI contributes to achieving inclusive sustainable growth by improving the efficiency of this banking sector.

Table 4 exhibits the results of the Simar-Wilson (2007) double bootstrapping regression (Algorithm 1) using baseline equation 2. Algorithm 1 only affects the estimated confidence intervals and standard errors and it does not fully provide the bias-corrected efficiency score. At this stage, we can use the externally calculated efficiency score to find the determinants of Islamic banks' efficiency.

Table 4.

Bank efficiency, financial inclusion and inclusive sustainable growth Algorithm 1

\begin{tabular}{lcccccc}
\hline $\begin{array}{l}\text { Dep. var: } \\
\text { Efficiency score }\end{array}$ & $\begin{array}{c}\text { Exp. } \\
\text { sign }\end{array}$ & $\begin{array}{c}\text { Model 1 } \\
\text { (ATMs per } \\
\text { 100k adults) }\end{array}$ & $\begin{array}{c}\text { Model 2 } \\
\text { (Branch } \\
\text { per 100k } \\
\text { adults) }\end{array}$ & $\begin{array}{c}\text { Model 3 } \\
\text { (ATMs } \\
\text { per 1k } \\
\text { km2) }\end{array}$ & $\begin{array}{c}\text { Model 4 } \\
\text { (Branch } \\
\text { per 1k } \\
\text { km2) }\end{array}$ & $\begin{array}{c}\text { Model 5 } \\
\text { (\# of bank } \\
\text { account per } \\
\text { 1k adults) }\end{array}$ \\
\hline Profitability & + & $0.017^{* * *}$ & $0.017^{* * *}$ & $0.021^{* * *}$ & $0.017^{* * *}$ & $0.017^{* * *}$ \\
Size & + & $(0.004)$ & $(0.004)$ & $(0.004)$ & $(0.004)$ & $(0.004)$ \\
& & $0.096^{* * *}$ & $0.096^{* * *}$ & $0.085^{* * *}$ & $0.099^{* * *}$ & $0.093^{* * *}$ \\
Credit risk & $(0.007)$ & $(0.006)$ & $(0.005)$ & $(0.006)$ & $(0.006)$ \\
& $+/-$ & $0.001^{* *}$ & $0.001^{* *}$ & $0.001^{*}$ & $0.001^{* *}$ & $0.001^{* *}$ \\
Capitalisation & + & $(0.001)$ & $(0.001)$ & $(0.001)$ & $(0.001)$ & $(0.001)$ \\
& & $0.002^{* * *}$ & $0.003^{* * *}$ & $0.003^{* * *}$ & $0.004^{* * *}$ & $0.003^{* * *}$ \\
GDP growth & $+(0.001)$ & $(0.001)$ & $(0.001)$ & $(0.001)$ & $(0.001)$ \\
& & -0.007 & -0.004 & $-0.012^{* * *}$ & $-0.009^{* * *}$ & $-0.035^{* *}$ \\
Inflation & & $(0.005)$ & $(0.003)$ & $(0.003)$ & $(0.002)$ & $(0.014)$ \\
& - & $-0.007^{* * *}$ & $-0.007^{* * *}$ & $-0.003^{* * *}$ & $-0.004^{* * *}$ & $-0.002^{*}$ \\
Financial inclusion & + & $(0.001)$ & $(0.001)$ & $(0.001)$ & $(0.001)$ & $(0.001)$ \\
& & 0.002 & 0.009 & $0.033^{* * *}$ & $0.028^{* * *}$ & $0.065^{* * *}$ \\
GDP Financial & + & $0.010)$ & $(0.013)$ & $(0.007)$ & $(0.007)$ & $(0.015)$ \\
inclusion & & 0.001 & 0.001 & $0.004^{* * *}$ & $0.001^{* * *}$ & $0.005^{* *}$ \\
\hline
\end{tabular}


Table 4.

Bank efficiency, financial inclusion and inclusive sustainable growth Algorithm 1 (Continued)

\begin{tabular}{lcccccc}
\hline $\begin{array}{l}\text { Dep. var: } \\
\text { Efficiency score }\end{array}$ & $\begin{array}{c}\text { Exp. } \\
\text { sign }\end{array}$ & $\begin{array}{c}\text { Model 1 } \\
\text { (ATMs per } \\
\text { 100k adults) }\end{array}$ & $\begin{array}{c}\text { Model 2 } \\
\text { (Branch } \\
\text { per 100k } \\
\text { adults) }\end{array}$ & $\begin{array}{c}\text { Model 3 } \\
\text { (ATMs } \\
\text { per 1k } \\
\text { km2) }\end{array}$ & $\begin{array}{c}\text { Model 4 } \\
\text { (Branch } \\
\text { per 1k } \\
\text { km2) }\end{array}$ & $\begin{array}{c}\text { Model 5 } \\
\text { (\# of bank } \\
\text { account per } \\
\text { 1k adults) }\end{array}$ \\
\hline Year fixed effect & & Yes & Yes & Yes & Yes & Yes \\
Wald chi2 & $401.71^{* * *}$ & $376.55^{* * *}$ & $493.77^{* * *}$ & $505.81^{* * *}$ & $534.11^{* * *}$ \\
Observations & & 565 & 565 & 565 & 565 & 458 \\
Efficient DMUs & 90 & 90 & 90 & 90 & 76 \\
Bootstrap Reps. & 1,000 & 1,000 & 1,000 & 1,000 & 1,000 \\
\hline
\end{tabular}

Note: ${ }^{*} p<0.1 ;{ }^{* *} p<0.05 ;{ }^{* * *} p<0.01$. Dependent variable $=$ Input-oriented technical efficiency score under VRS using the DEA score. All other variables are explained in Table 2.

The findings in Table 4 show that FI is significantly positively related to Islamic banks' efficiency based on all models except Models 1 and 2. For all cases, it is clearly evident that the greater efficiency of Islamic banks is associated with higher FI as proven by its significant and positive ( $1 \%$ level) coefficients, apart from demographic penetrations. Based on the mean efficiency score of $65.2 \%$, it is clear that the effect is statistically significant.

As Algorithm 1 does not consider bias-corrected efficiency, we have run the Simar-Wilson (2007) double bootstrapping Algorithm 2 regression model. During this process, we use the bias-corrected efficiency score as a dependent variable. In this regression, externally calculated efficiency scores are not allowed as the regression internally estimates bias-corrected efficiency. In this procedure, we use 1,500 replications in the bias correction bootstrap and 2,000 replications in the bootstrap similar to Algorithm 1.

Table 5 shows the results of the Simar-Wilson (2007) efficiency analysis using Algorithm 2. In most cases, the significance and sign of the variables does not change in Algorithm 2. However, the bias-corrected efficiency scores improve the estimated confidence intervals and the coefficients, as well as the significance of the models (based on the higher Wald chi ${ }^{2}$ value). In Algorithm 2, the study also finds a significant positive relationship between FI and Islamic bank efficiency.

We expected a positive relationship between GDP growth and Islamic banks' efficiency as growth could exalt the efficiency of the banking sector. However, the results show that GDP growth has a negative effect on Islamic banks' efficiency. Interestingly, the interaction between FI and GDP growth is positively and significantly related to the efficiency of Islamic banks. The results suggest that when GDP growth is associated with Islamic banks' efficiency alone, it reflects a negative relationship; however, when FI interacts with GDP growth, the relationship with Islamic banks' efficiency becomes strong and positive.

Profitability is positively and significantly related to Islamic banks' efficiency at a $1 \%$ level, regardless of the penetration of financial outreach and usage dimensions. The size of banks also has a significant positive effect at a $1 \%$ level for the technical efficiency of Islamic banks. Surprisingly, credit risk has a positive relationship with Islamic banks' efficiency. Credit risk is significant at a $5 \%$ 
level, regardless of the penetration of financial outreach and usage dimensions. Furthermore, capitalisation is positively related with overall Islamic banks' technical efficiency at a $1 \%$ level. Finally, inflation rates have a negative effect on Islamic banks' efficiency, as expected.

Table 5.

Bank efficiency, financial inclusion and inclusive sustainable growth - Algorithm 2

\begin{tabular}{|c|c|c|c|c|c|c|}
\hline $\begin{array}{l}\text { Dep. var: Efficiency } \\
\text { score }\end{array}$ & $\begin{array}{l}\text { Exp. } \\
\text { sign }\end{array}$ & $\begin{array}{l}\text { Model } 1 \\
\text { (ATMs } \\
\text { per 100k } \\
\text { adults) }\end{array}$ & $\begin{array}{c}\text { Model } 2 \\
\text { (Branch } \\
\text { per 100k } \\
\text { adults) }\end{array}$ & $\begin{array}{c}\text { Model } 3 \\
\text { (ATMs per } \\
\text { 1k km2) }\end{array}$ & $\begin{array}{c}\text { Model } 4 \\
\text { (Branch } \\
\text { per 1k } \\
\text { km2) }\end{array}$ & $\begin{array}{c}\text { Model } 5 \\
\text { (\# of bank } \\
\text { account } \\
\text { per } 1 k \\
\text { adults) }\end{array}$ \\
\hline Profitability & + & $\begin{array}{l}0.020^{* * *} \\
(0.003)\end{array}$ & $\begin{array}{l}0.021^{* * *} \\
(0.003)\end{array}$ & $\begin{array}{l}0.025^{* * *} \\
(0.003)\end{array}$ & $\begin{array}{l}0.022^{* * *} \\
(0.003)\end{array}$ & $\begin{array}{c}0.021^{* * *} \\
(0.003)\end{array}$ \\
\hline Size & + & $\begin{array}{l}0.095^{* * *} \\
(0.004)\end{array}$ & $\begin{array}{l}0.094^{* * *} \\
(0.004)\end{array}$ & $\begin{array}{c}0.083^{* * *} \\
(0.004)\end{array}$ & $\begin{array}{c}0.091^{* * *} \\
(0.004)\end{array}$ & $\begin{array}{c}0.099^{* * *} \\
(0.004)\end{array}$ \\
\hline Credit risk & $+/-$ & $\begin{array}{l}0.001^{* *} \\
(0.001)\end{array}$ & $\begin{array}{l}0.001^{* *} \\
(0.001)\end{array}$ & $\begin{array}{l}0.001^{*} \\
(0.001)\end{array}$ & $\begin{array}{l}0.001^{* * *} \\
(0.001)\end{array}$ & $\begin{array}{l}0.001^{* *} \\
(0.001)\end{array}$ \\
\hline Capitalisation & + & $\begin{array}{l}0.003^{* * *} \\
(0.000)\end{array}$ & $\begin{array}{l}0.003^{* * *} \\
(0.000)\end{array}$ & $\begin{array}{l}0.003^{* * *} \\
(0.000)\end{array}$ & $\begin{array}{l}0.003^{* * *} \\
(0.000)\end{array}$ & $\begin{array}{l}0.003^{* * *} \\
(0.000)\end{array}$ \\
\hline GDP growth & $+/-$ & $\begin{array}{l}-0.000 \\
(0.003)\end{array}$ & $\begin{array}{l}-0.000 \\
(0.002)\end{array}$ & $\begin{array}{l}-0.005^{* *} \\
(0.003)\end{array}$ & $\begin{array}{c}-0.005^{* * *} \\
(0.002)\end{array}$ & $\begin{array}{l}-0.005 \\
(0.010)\end{array}$ \\
\hline Inflation & - & $\begin{array}{c}-0.006^{* * *} \\
(0.001)\end{array}$ & $\begin{array}{c}-0.006^{* * *} \\
(0.001)\end{array}$ & $\begin{array}{c}-0.004^{* * *} \\
(0.001)\end{array}$ & $\begin{array}{l}-0.005^{* * *} \\
(0.001)\end{array}$ & $\begin{array}{l}-0.003^{* * *} \\
(0.001)\end{array}$ \\
\hline Financial inclusion & + & $\begin{array}{c}0.003 \\
(0.007)\end{array}$ & $\begin{array}{c}0.011 \\
(0.009)\end{array}$ & $\begin{array}{l}0.025^{* * *} \\
(0.005)\end{array}$ & $\begin{array}{l}0.024^{* * *} \\
(0.005)\end{array}$ & $\begin{array}{l}0.063^{* * *} \\
(0.010)\end{array}$ \\
\hline GDP x Financial inclusion & + & $\begin{array}{l}-0.000 \\
(0.001)\end{array}$ & $\begin{array}{l}-0.000 \\
(0.000)\end{array}$ & $\begin{array}{l}0.002^{*} \\
(0.001)\end{array}$ & $\begin{array}{c}0.001^{* * *} \\
(0.001)\end{array}$ & $\begin{array}{l}0.001^{* *} \\
(0.001)\end{array}$ \\
\hline Year fixed effect & & Yes & Yes & Yes & Yes & Yes \\
\hline Wald chi2 & & $945.86^{* * *}$ & $936.19^{* * *}$ & $1,087.67^{* * *}$ & $1,103.38^{* * *}$ & $1,694.35^{* * *}$ \\
\hline Observations & & 649 & 649 & 651 & 651 & 528 \\
\hline Number of reps (bc) & & 1,000 & 1,000 & 1,000 & 1,000 & 1,000 \\
\hline Bootstrap Reps. & & 1,000 & 1,000 & 1,000 & 1,000 & 1,000 \\
\hline
\end{tabular}

Note: ${ }^{*} p<0.1 ;{ }^{* *} p<0.05 ;{ }^{* * *} p<0.01$. Dependent variable= bias-corrected Farrell input-oriented technical efficiency score under VRS using Simar-Wilson (2007) double bootstrapping regression. bc = bias-corrected. All other variables are explained in Table 2.

The results of Algorithms 1 and 2 show that standalone GDP growth has a negative effect on Islamic banks' efficiency, whereas the interaction of FI and GDP growth still has a significant positive relationship with bias-corrected efficiency, apart from demographic penetration. However, using the bias-corrected efficiency score, it is clear that a smooth and inclusive financial sector is positively associated with higher Islamic banking efficiency, regardless of the penetrations and dimensions of FI. 


\subsection{Robustness Test}

We examine the robustness of the key results using the following method. To construct an FI index using the combined dimensions of FI, principal component analysis (PCA) has been employed. This FI index is later used to investigate the association of FI with banks' efficiency in various dimensions.

To observe the robustness of the main results, this study uses an alternative proxy of FI using PCA. PCA helps us achieve the single linear combination of the FI proxies from the first principal component, which explicates most of the variations visible in these proxies. Thus, this single index effectively deals with the issue of over-parameterisation and multicollinearity. There are four variables that comprise the financial outreach dimension and from which we, with the help of the PCA, capture common variation and formulate the single index of the financial outreach dimension. We then combine both the single index of the financial outreach dimension and the usage dimensions of FI to create a single FI index using PCA. We consider two indices of FI; the first index is comprised of financial outreach (both demographic and geographic penetrations) but without usage; the second index is more comprehensive as it includes both financial outreach and usage dimensions.

In this analysis, we have used Simar-Wilson (2007) regressions for Algorithms 1 and 2 . In these regressions, Farrell's (1957) input-oriented technical efficiency and bias-corrected input-oriented technical efficiency score under VRS are used as dependent variables for Algorithm 1 and Algorithm 2, respectively.

Table 6.

Bank efficiency, financial inclusion and inclusive sustainable growth - PCA

\begin{tabular}{|c|c|c|c|c|c|}
\hline Dep. var: efficiency & $\begin{array}{l}\text { Exp. } \\
\text { sign }\end{array}$ & $\begin{array}{c}\text { Model 1 } \\
\text { (PCA without } \\
\text { usage) }\end{array}$ & $\begin{array}{l}\text { Model } 2 \\
\text { (PCA with } \\
\text { usage) }\end{array}$ & $\begin{array}{c}\text { Model } 3 \\
\text { (PCA without } \\
\text { usage) }\end{array}$ & $\begin{array}{c}\text { Model } 4 \\
\text { (PCA with } \\
\text { usage) }\end{array}$ \\
\hline & & \multicolumn{2}{|c|}{ Algorithm \#1 } & \multicolumn{2}{|c|}{ Algorithm \#2 } \\
\hline \multirow[t]{2}{*}{ Profitability } & + & $0.022^{* * *}$ & $0.018^{* * *}$ & $0.024^{* * *}$ & $0.021^{* * *}$ \\
\hline & & $(0.004)$ & $(0.004)$ & $(0.003)$ & $(0.003)$ \\
\hline \multirow[t]{2}{*}{ Size } & + & $0.086^{* * *}$ & $0.091^{* * *}$ & $0.085^{* * *}$ & $0.097^{* * *}$ \\
\hline & & $(0.006)$ & $(0.006)$ & $(0.004)$ & $(0.004)$ \\
\hline \multirow[t]{2}{*}{ Credit risk } & $+/-$ & $0.001^{*}$ & $0.001^{*}$ & $0.001^{* *}$ & $0.001^{* *}$ \\
\hline & & $(0.001)$ & $(0.001)$ & $(0.001)$ & $(0.001)$ \\
\hline \multirow[t]{2}{*}{ Capitalisation } & + & $0.002^{* * *}$ & $0.003^{* * *}$ & $0.003^{* * *}$ & $0.003^{* * *}$ \\
\hline & & $(0.001)$ & $(0.001)$ & $(0.001)$ & $(0.001)$ \\
\hline \multirow[t]{2}{*}{ GDP growth } & $+/-$ & -0.002 & -0.001 & -0.001 & -0.002 \\
\hline & & $(0.002)$ & $(0.003)$ & $(0.001)$ & $(0.002)$ \\
\hline \multirow[t]{2}{*}{ Inflation } & - & $-0.005^{* * *}$ & -0.002 & $-0.005^{* * *}$ & $-0.003^{* * *}$ \\
\hline & & $(0.001)$ & $(0.001)$ & $(0.001)$ & $(0.001)$ \\
\hline \multirow[t]{2}{*}{ Financial inclusion } & + & $0.020^{* * *}$ & $0.057^{* * *}$ & $0.015^{* * *}$ & $0.051^{* * *}$ \\
\hline & & $(0.006)$ & $(0.013)$ & $(0.004)$ & $(0.008)$ \\
\hline \multirow{2}{*}{$\begin{array}{l}\text { GDP x Financial } \\
\text { inclusion }\end{array}$} & + & $0.003^{* * *}$ & 0.003 & $0.001^{*}$ & -0.001 \\
\hline & & $(0.001)$ & $(0.002)$ & $(0.001)$ & $(0.001)$ \\
\hline
\end{tabular}


Table 6.

Bank efficiency, financial inclusion and inclusive sustainable growth - PCA (Continued)

\begin{tabular}{lllllc}
\hline Dep. var: efficiency & $\begin{array}{c}\text { Exp. } \\
\text { sign }\end{array}$ & $\begin{array}{c}\text { Model 1 } \\
\text { (PCA without } \\
\text { usage) }\end{array}$ & $\begin{array}{c}\text { Model 2 } \\
\text { (PCA with } \\
\text { usage) }\end{array}$ & $\begin{array}{c}\text { Model 3 } \\
\text { (PCA without } \\
\text { usage) }\end{array}$ & $\begin{array}{c}\text { Model 4 } \\
\text { (PCA with } \\
\text { usage) }\end{array}$ \\
\hline Year fixed effect & \multicolumn{2}{c}{ Algorithm \#1 } & \multicolumn{2}{c}{ Algorithm \#2 } \\
Wald chi2 & Yes & Yes & Yes & Yes \\
Observations & $444.42^{* * *}$ & $516.61^{* * *}$ & $1,033.00^{* * *}$ & $1,606.53^{* * *}$ \\
Efficient DMUs & 565 & 458 & 650 & 529 \\
Number of reps (bc) & 90 & 76 &. &. \\
Bootstrap Reps. & &. & 1,000 & 1,000 \\
\hline
\end{tabular}

Note: ${ }^{*} p<0.1 ;{ }^{* *} p<0.05 ;{ }^{* * *} p<0.01$. Dependent variable $=$ Farrell's input-oriented technical efficiency and bias-corrected Farrell's input-oriented technical efficiency score under VRS using Simar-Wilson (2007) double bootstrapping regression. PCA \& bc refer to principal component analysis, and bias-corrected respectively. All other variables are explained in Table 2.

In Table 6, the findings also suggest that FI is significantly related with Islamic banking efficiency through the provision of a positive link between them and the interaction of FI and GDP growth has a positive relationship with the efficiency of Islamic banks. We also consider Tobit regression, OLS and GMM for the robustness of the results, but find no significant differences. We have not provided the results in this manuscript; however, the results are available upon request.

\subsection{Analysis}

Constructing a yearly frontier is more flexible and more appropriate than constructing a single multi-year frontier for banks (Rosman et al., 2014). Therefore, for every year, this study uses a separate annual frontier for all Islamic banks due to their similar operational practices. Among many, the key benefit of utilising panel data is to create a scope of observing each bank several times during a given period (Isik \& Hassan, 2002). However, its application is crucial for those business sectors that have randomly changing atmospheres because the technology that banks use might not be as effective all the time (Sufian \& Noor, 2009).

On average, the total deposits of Islamic banks are higher than their total loans. The pattern is similar to Doan et al. (2018), who studied the sample of commercial banks and Rosman et al. (2014) who analysed Islamic banks. It is worth noting that high-standard deviations visualise large differences in the output variables among sample countries. Overall, the efficiency of the sample Islamic banks is volatile during the period 2011-2017. The low efficiency score of Islamic banks suggests that banking sectors in various countries are still suffering the consequences of the GFC. The average efficiency score of this study advocates that to produce the same unit of outputs that Islamic banks have already produced, $34.8 \%$ of the inputs could have been saved by the banks. In other words, by spending $65.2 \%$ of the inputs used by Islamic banks, they could have made the same unit of outputs. The findings are quite similar to Rosman et al. (2014) who analysed Asian Islamic 
banks. Based on the findings, Egypt has demonstrated an upward efficiency trend since 2012. Islamic banks in Bangladesh, Malaysia, Mauritia, Qatar, Tunisia, and Sudan are performing as efficiently as the others. Interestingly, in spite of being war-affected countries, Islamic banks in Iraq and Palestine are performing efficiently.

FI plays a significant role in Islamic banks' efficiency, both statistically and economically. The economic effect suggests that the soundness of individual banks can be enriched through FI. Moreover, through the means of a sound inclusive financial sector, banks can bring in plenty of cheap retail deposits from their vast clientele. They can also remove SME-related financing constraints, resolve the hazards seen in the post-financial period, and mitigate problems pertinent to asset substitutions (Wangmo, 2016). Hence, banks that have a sound and inclusive financial environment enjoy a higher level of financial efficiency. However, FI has a negative impact on the financial system due to excessive financial innovations (Mani, 2016). This argument motivates the central banks of various countries to tighten their financial regulations following the GFC. This tightening policy interrupts the ease of access to financial services for low-income groups (Mani, 2016). However, our results suggest that FI is not the cause of financial crisis; rather, it helps to create financial stability through a more diversified and financial system. This idea is supported by Hannig and Jansen (2010).

The study further shows a negative effect of GDP growth on the efficiency of Islamic banking. We expected a positive relationship between GDP growth and bank efficiency as growth might promote the efficiency of the banking sector, but a negative relationship was determined. The finding contradicts previous studies (Banna et al., 2019b; Grigorian \& Manole, 2006). Interestingly, the interaction of FI with GDP growth creates a positive link between the interaction effect (FI and GDP growth) and Islamic banks' efficiency, which suggests that FI has a significant role in sustainable growth. Our results are in line with Ahamed and Mallick (2019) and Rillo (2014) who argue that FI brings inclusive growth and development into a society, which, in turn, leads to greater economic stability and sustainable financial growth.

We consider the effects of the interaction between FI and GDP growth, because when talking about the real or sustainable growth of any country, GDP appears to be the main determinant. In their empirical study that determined the economic growth of various countries across the world, Gould and Ruffin (1993) consider GDP to be the key determinant of the economic growth of countries. Apart from this, many other scholars, for example, Maddison (1991) and Ben-David and Papell (1994) also see GDP as a pivotal factor for the long-term economic development of any country. In most cases, an increase in GDP suggests that a country is advancing; however, for highly developed countries, an increase or decrease in GDP does not necessarily measure economic growth. As both inclusive finance and GDP growth promote the economic advancement of any country, both of their interaction effects bring sustainable economic growth in a heightened manner.

Our findings on control variables are also supported by existing studies. Profitability is positively and significantly related to Islamic banks' efficiency; this was clearly explained in some studies (Banna et al., 2019b; Pasiouras, 2008; Sufian, 2009) in which scholars demonstrate a significant positive relationship 
between profitability and bank efficiency. Thus, it is evident that by augmenting their profitability, banks can become more efficient; this was supported by Sufian (2009). Banks with more profitability are seen as more efficient than those with less profitability. The size of banks has a positive effect on Islamic banks' technical efficiency, which is also supported by Hassan (2006). Larger Islamic banks that have skilled management teams can produce more efficient outputs from their limited inputs.

Surprisingly, credit risk has a positive relationship with the efficiency of Islamic banks. This finding seems to contradiction some past studies (Kwan \& Eisenbeis, 1997; Resti, 1997) in which researchers have obtained a negative association between bank efficiency and problem loans. In this regard, Ahmad and Hassan (2007) propose to keep this ratio as low as possible. However, the result is similar for Rosman et al. (2014) who observed a positive association after conducting a research on the Islamic banks in Asia and the Middle East. They explain that it might be a possible reason behind the positive association between credit risk and efficiency; during the research period, to be more careful in terms of dealing with their finance-related affairs, financing is given more attention by banks that are more efficient. Therefore, credit risk and Islamic banking efficiency are positively linked.

Capitalisation is positively related with the Islamic banks' overall technical efficiency. The result is similar to earlier studies (Banna et al., 2019b; Casu \& Girardone, 2004; Sufian \& Noor, 2009), which showed that more equity can mitigate future losses. Thus, ceteris paribus, less leverage (i.e. more equity) has been used more readily by efficient banks than less efficient banks. Finally, inflation has a negative relationship with Islamic banks' efficiency. As expected, this confirms the detrimental effect of economic instability on the efficiency of the banking sector. Thus, our results support Tajgardoon et al. (2012).

It is clear from the various dimensions of analysis that the efficiency of Islamic banks is greatly influenced by efficient and productive FI.

\section{CONCLUSION}

\subsection{Conclusion}

Since the GFC, FI has gained the considerable attention of scholars, stakeholders, researchers and financial analysts; however, a limited number of studies have been undertaken to observe the impact of FI on the smooth operation of Islamic banks through heightened efficiency levels. Hence, this study aims to measure the nonbias and bias-corrected efficiency of Islamic banks and to see how FI encourages inclusive sustainable growth by improving Islamic banks' efficiency.

The findings show that the efficiency trends of Islamic banks in most countries are inconsistent post-GFC, which denotes that the consequences of the GFC still exist within the banking industry. However, Islamic banks in Bangladesh, Malaysia, Mauritia, Qatar, Tunisia, and Sudan are performing efficiently and, interestingly, in spite of being war-affected countries, Islamic banks in Iraq and Palestine have shown improved efficiency trends. The results foreground that FI plays a key role in improving Islamic banks' efficiency. The interaction of FI and GDP growth suggests that FI plays a significant role in sustainable growth, which 
creates a positive relationship between inclusive sustainable growth and Islamic banks' efficiency. Our results are robust due to the use of various tests. This suggests that efficient and inclusive financial systems accelerate Islamic banking efficiency, regardless of penetrations and dimensions.

\subsection{Recommendation}

This paper measures the efficiency of Islamic banks post-GFC and explores how this efficiency contributes to inclusive sustainable growth; policymakers, regulators, practitioners, financial analysts and others involved in financial affairs are expected to have a good insight into FI, Islamic banking efficiency and inclusive economic growth. Every individual working for the exaltation of financial sector should focus extensively on the implementation of FI so that banking efficiency can be achieved; this will, subsequently, bring sustainable economic growth to society. Islamic scholars should work together to spread the importance of Islamic finance and FI in attaining inclusive sustainable growth. The pivotal focus of FI is to 'bank' unbanked people. Therefore, Islamic banks should put more focus on how to bank the unbanked, particularly those who are underprivileged and living in rural areas.

Then, with the test of time, innovative, environmentally friendly and Shari'acompliant financial services/products should be launched that will attract more clients, mitigate the demand of time, and remove finance-related constraints from the Islamic banking industry. Islamic banks should properly implement digital financial services (the adoption of Fintech solutions, e.g. e-wallet/mobile banking) to keep pace with this age of competition in which their counterpart conventional banks are moving forward. Such digital finance will help minimise cost and maximise efficiency. In launching digital financial services, clients' transaction security must be ensured using the latest and most secure software.

Along with a better understanding of financial stability, financial literacy is also very important. Thus, to disseminate financial literacy to clients with lower levels of education, campaigns should be arranged. To render more services to clients, more efficient banking branches are required. Hence, more Islamic banking branches (physical or virtual) should be established. The number of ATMs should be augmented with consideration given to the reachability of people living in remote areas.

Finally, research depicting the role of FI on banking efficiency and financial stability is an ongoing process; hence, the findings of this paper can be expanded by future studies in many ways, such as a comparative study between conventional and Islamic banks to measure efficiency through FI, and comparing efficiency among different branches of Islamic banks within the same country or with other countries. Future studies could create a relationship between digital FI and banks' efficiency.

\section{ACKNOWLEDGEMENTS}

The authors would like to thank the anonymous reviewers, Prof M Kabir Hassan, Prof Mansor Ibrahim, and Dr Rubi Ahmad for their critical reviews 
and precious comments. This research was partially funded by the Ungku Aziz Centre for Development Studies (UACDS/CPDS) and the Faculty of Economics and Administration (FEA), University of Malaya (Grant numbers: PD004-2018 and GPF006P-2019).

\section{REFERENCES}

Abdul-Majid, M., Saal, D. S., \& Battisti, G. (2010). Efficiency in Islamic and Conventional Banking: An International Comparison. Journal of Productivity Analysis, 34(1), 25-43.

Ahamed, M. M., Ho, S. J., Mallick, S., \& Matousek, R. (2018). Inclusive Banking, Financial Regulation and Bank Performance: Cross-country Evidence. DECRG Kuala Lumpur Seminar Series. World Bank Kuala Lumpur.

Ahamed, M. M., \& Mallick, S. K. (2019). Is Financial Inclusion Good for Bank Stability? International Evidence. Journal of Economic Behavior E Organization, 157 (January 2019), 403-427. doi:10.1016/j.jebo.2017.07.027

Ahmad, A. U. F., \& Hassan, M. K. (2007). Regulation and Performance of Islamic Banking in Bangladesh. Thunderbird International Business Review, 49(2), 251277.

Al-Smadi, M. O. (2018). The Role of Financial Inclusion in Financial Stability: Lesson from Jordan. Banks and Bank Systems, 13(4), 31.

Allen, F., Carletti, E., Cull, R., Qian, J. Q., Senbet, L., \& Valenzuela, P. (2014). The African Financial Development and Financial Inclusion Gaps. Journal of African Economies, 23(5), 614-642.

Badunenko, O., \& Tauchmann, H. (2018). Simar and Wilson Two-stage Efficiency Analysis for Stata. Retrieved from https://EconPapers.repec.org/ RePEc:zbw:iwqwdp:082018

Banerjee, A., Duflo, E., Glennerster, R., \& Kinnan, C. (2015). The Miracle of Microfinance? Evidence from a Randomized Evaluation. American Economic Journal: Applied Economics, 7(1), 22-53.

Banker, R. D., Charnes, A., \& Cooper, W. W. (1984). Some Models for Estimating Technical and Scale Inefficiencies in Data Envelopment Analysis. Management Science, 30(9), 1078-1092.

Banna, H., Ahmad, R., \& Koh, E. H. (2017). Determinants of Commercial Banks' Efficiency in Bangladesh: Does Crisis matter? The Journal of Asian Finance, Economics and Business (JAFEB), 4(3), 19-26.

Banna, H., Ahmad, R., \& Koh, E. H. Y. (2018). How Does Total Quality Management Influence the Loan Quality of the Bank? Total Quality Management E Business Excellence, 29(3-4), 287-300. doi:10.1080/14783363.2016.1180954

Banna, H., Alam, M. R., Ahmad, R., \& Sari, N. M. (2020). Does Financial Inclusion Drive the Islamic Banking Efficiency? A Post-Financial Crisis Analysis. The Singapore Economic Review. doi:10.1142/s0217590819420050

Banna, H., Rana, M. S., Ismail, I., \& Ismail, N. (2019a). Quantifying the Managerial Ability of Microfinance Institutions: Evidence from Latin America. Journal of International Development. doi:10.1002/jid.3419

Banna, H., Shah, S. K. B., Noman, A. H. M., Ahmad, R., \& Masud, M. M. (2019b). Determinants of Sino-ASEAN Banking Efficiency: How Do Countries Differ? Economies, 7(1), 13. doi:10.3390/economies7010013 
Beck, T., Demirguc-Kunt, A., \& Martínez-Pería, M. S. (2007). Reaching Out: Access To and Use of Banking Services across Countries. Journal of Financial Economics, 85(1), 234-266.

Beck, T., Lin, C., \& Ma, Y. (2014). Why Do Firms Evade Taxes? The Role of Information Sharing and Financial Sector Outreach. The Journal of Finance, 69(2), 763-817.

Ben-David, D., \& Papell, D. H. (1994). The Great wars, the Great Crash, and the Unit Root Hypothesis: Some New Evidence about An Old Stylized Fact.

Berger, A. N., \& Humphrey, D. B. (1997). Efficiency of Financial Institutions: International Survey and Directions for Future Research. European Journal of Operational Research, 98(2), 175-212.

Brickley, J. A., Linck, J. S., \& Smith Jr, C. W. (2003). Boundaries of the Firm: Evidence from the Banking Industry. Journal of Financial Economics, 70(3), 351-383.

Bruhn, M., \& Love, I. (2014). The Real Impact of Improved Access to Finance: Evidence from Mexico. The Journal of Finance, 69(3), 1347-1376.

Burgess, R., \& Pande, R. (2005). Do Rural Banks matter? Evidence from the Indian Social Banking Experiment. American Economic Review, 95(3), 780-795.

Casu, B., \& Girardone, C. (2004). Financial Conglomeration: Efficiency, Productivity and Strategic Drive. Applied Financial Economics, 14(10), 687-696.

Charnes, A., Cooper, W. W., \& Rhodes, E. (1978). Measuring the Efficiency of Decision-making units. European Journal of Operational Research, 2(6), 429-444.

Cihák, M. M., \& Hesse, H. (2008). Islamic Banks and Financial Stability: An Empirical Analysis. International Monetary Fund.

Daraio, C., Simar, L., \& Wilson, P. W. (2018). Central Limit Theorems for Conditional Efficiency Measures and Tests of the 'Separability' Condition in Non-parametric, Two-stage Models of Production. The Econometrics Journal, 21(2), 170-191.

Demirgüç-Kunt, A., \& Huizinga, H. (2010). Bank Activity and Funding Strategies: The impact on Risk and Returns. Journal of Financial Economics, 98(3), 626-650.

Demirguc-Kunt, A., Klapper, L., Singer, D., Ansar, S., \& Hess, J. (2018). The Global Findex Database 2017: Measuring Financial Inclusion and the Fintech Revolution. The World Bank.

Di Patti, E. B., \& Dell'Ariccia, G. (2001). Bank Competition and Firm Creation. International Monetary Fund.

Dienillah, A. A., Anggraeni, L., \& Sahara, S. (2018). Impact of Financial Inclusion on Financial Stability based on Income Group Countries. Buletin Ekonomi Moneter dan Perbankan, 20(4), 429-442.

Doan, A.-T., Lin, K.-L., \& Doong, S.-C. (2018). What Drives Bank Efficiency? The Interaction of Bank Income Diversification and Ownership. International Review of Economics \& Finance, 55, 203-219.

Farrell, M. J. (1957). The Measurement of Productive Efficiency. Journal of the Royal Statistical Society: Series A (General), 120(3), 253-281.

Galor, O., \& Moav, O. (2004). From Physical to Human Capital Accumulation: Inequality and the process of Development. The Review of Economic Studies, 71(4), 1001-1026.

Gardener, E., Molyneux, P., \& Nguyen-Linh, H. (2011). Determinants of Efficiency in South East Asian Banking. The Service Industries Journal, 31(16), 2693-2719. 
Gould, D. M., \& Ruffin, R. J. (1993). What Determines Economic Growth? Economic and Financial Policy Review(Apr), 25-40.

Grigorian, D. A., \& Manole, V. (2006). Determinants of Commercial Bank Performance in transition: An Application of Data Envelopment Analysis. Comparative Economic Studies, 48(3), 497-522.

Han, R., \& Melecky, M. (2013). Financial Inclusion for Financial Stability: Access to Bank Deposits and the Growth of Deposits in the Global Financial Crisis. The World Bank.

Hannig, A., \& Jansen, S. (2010). Financial Inclusion and Financial Stability: Current Policy Issues. ADBI Working Paper. Asian Development Bank Institute. Tokyo.

Hassan, M. K. (2006). The X-Efficiency in Islamic banks. Islamic Economic Studies, 13, 50-78.

Iqbal, M., \& Llewellyn, D. T. (2002). Islamic Banking and Finance: New Perspectives on Profit Sharing and Risk. Edward Elgar Publishing.

Isik, I., \& Hassan, M. K. (2002). Technical, Scale and Allocative Efficiencies of Turkish Banking Industry. Journal of Banking E Finance, 26(4), 719-766.

Jahan, S., De, J., Jamaludin, F., Sodsriwiboon, P., \& Sullivan, C. (2019). The Financial Inclusion Landscape in the Asia-Pacific Region: A Dozen Key Findings. Retrieved from https://www.imf.org/ /media/Files/Publications/WP/2019/ WPIEA2019079.ashx

Jeong, H., \& Townsend, R. M. (2007). Sources of TFP Growth: Occupational Choice and Financial Deepening. Economic Theory, 32(1), 179-221.

Kacperczyk, M., \& Schnabl, P. (2013). How safe are Money Market Funds? The Quarterly Journal of Economics, 128(3), 1073-1122.

Kim, D.-W., Yu, J.-S., \& Hassan, M. K. (2018). Financial Inclusion and Economic Growth in OIC Countries. Research in International Business and Finance, 43, $1-14$.

Kwan, S., \& Eisenbeis, R. A. (1997). Bank Risk, Capitalization, and Operating Efficiency. Journal of Financial Services Research, 12(2-3), 117-131.

Le, T.-H., Chuc, A. T., \& Taghizadeh-Hesary, F. (2019). Financial Inclusion and Its Impact on Financial Efficiency and Sustainability: Empirical Evidence from Asia. Borsa Istanbul Review.

Maddison, A. (1991). Dynamic Forces in Capitalist Development: A Long-run Comparative view (Vol. 2). Oxford University Press Oxford.

Mani, M. (2016). Financial inclusion in South Asia-Relative Standing, Challenges and Initiatives. South Asian Survey, 23(2), 158-179.

Mirakhor, A. (2008). Lesson of the Recent Crisis for Islamic Finance. IIUM Journal of Economics and Management, 16(2), 132-138.

Mohieldin, M., Iqbal, Z., Rostom, A., \& Fu, X. (2011). The Role of Islamic Finance in Enhancing Financial Inclusion in Organization of Islamic Cooperation (OIC) Countries. The World Bank.

OECD (2008). Handbook on Constructing Composite Indicators: Methodology and User Guide. In: Organisation for Economic Co-operation and Development (OECD) Paris.

Owen, A. L., \& Pereira, J. M. (2018). Bank Concentration, Competition, and Financial Inclusion. Review of Development Finance, 8(1), 1-17. 
Pasiouras, F. (2008). Estimating the Technical and Scale Efficiency of Greek Commercial Banks: The Impact of Credit Risk, Off-Balance Sheet Activities, and International Operations. Research in International Business and Finance, 22(3), 301-318.

Prasad, E. S. (2010). Financial Sector Regulation and Reforms in Emerging Markets: An Overview. Retrieved from

Rashid, A., Yousaf, S., \& Khaleequzzaman, M. (2017). Does Islamic Banking Really Strengthen Financial Stability? Empirical Evidence from Pakistan. International Journal of Islamic and Middle Eastern Finance and Management, 10(2), 130-148.

Resti, A. (1997). Evaluating the Cost-Efficiency of the Italian Banking System: What can be learned from the Joint Application of Parametric and Non-parametric Techniques. Journal of Banking \& Finance, 21(2), 221-250.

Rillo, A. D. (2014). Overview of Financial Inclusion in Asia. In I. J. H. Park \& L. Kouqing (Eds.), Financial Inclusion in Asia: Country Surveys (pp. 1-5). Japan: Asian Development Bank Institute.

Rosman, R., Wahab, N. A., \& Zainol, Z. (2014). Efficiency of Islamic Banks during the Financial Crisis: An Analysis of Middle Eastern and Asian Countries. Pacific-Basin Finance Journal, 28, 76-90.

Simar, L., \& Wilson, P. W. (2007). Estimation and Inference in Two-stage, Semiparametric Models of Production processes. Journal of Econometrics, 136(1), 31-64.

Simar, L., \& Wilson, P. W. (2011). Two-stage DEA: Caveat Emptor. Journal of Productivity Analysis, 36(2), 205.

Sole, M. J. (2007). Introducing Islamic Banks into Conventional Banking Systems (EPub). International Monetary Fund.

Sufian, F. (2009). Determinants of Bank Efficiency during Unstable Macroeconomic Environment: Empirical Evidence from Malaysia. Research in International Business and Finance, 23(1), 54-77.

Sufian, F., \& Noor, M. A. N. M. (2009). The Determinants of Islamic Banks' Efficiency Changes: Empirical Evidence from the MENA and Asian Banking sectors. International Journal of Islamic and Middle Eastern Finance and Management, 2(2), 120-138.

Tajgardoon, G., Behname, M., \& Noormohamadi, K. (2012). Is Profitability as a Result of Market Power or Efficiency in Islamic Banking Industry. Economics and Finance Review, 2(5), 1-7.

Wangmo, C. (2016). Small and Medium Enterprise (SME) Financing Constraints in Developing countries: A Case Study of Bhutan. Victoria University,

World Bank Group. (2013). Global Financial Development Report 2014: Financial Inclusion (Vol. 2). World Bank Publications.

Zulkhibri, M. (2016). Financial Inclusion, Financial Inclusion Policy and Islamic Finance. Macroeconomics and Finance in Emerging Market Economies, 9(3), 303320. 


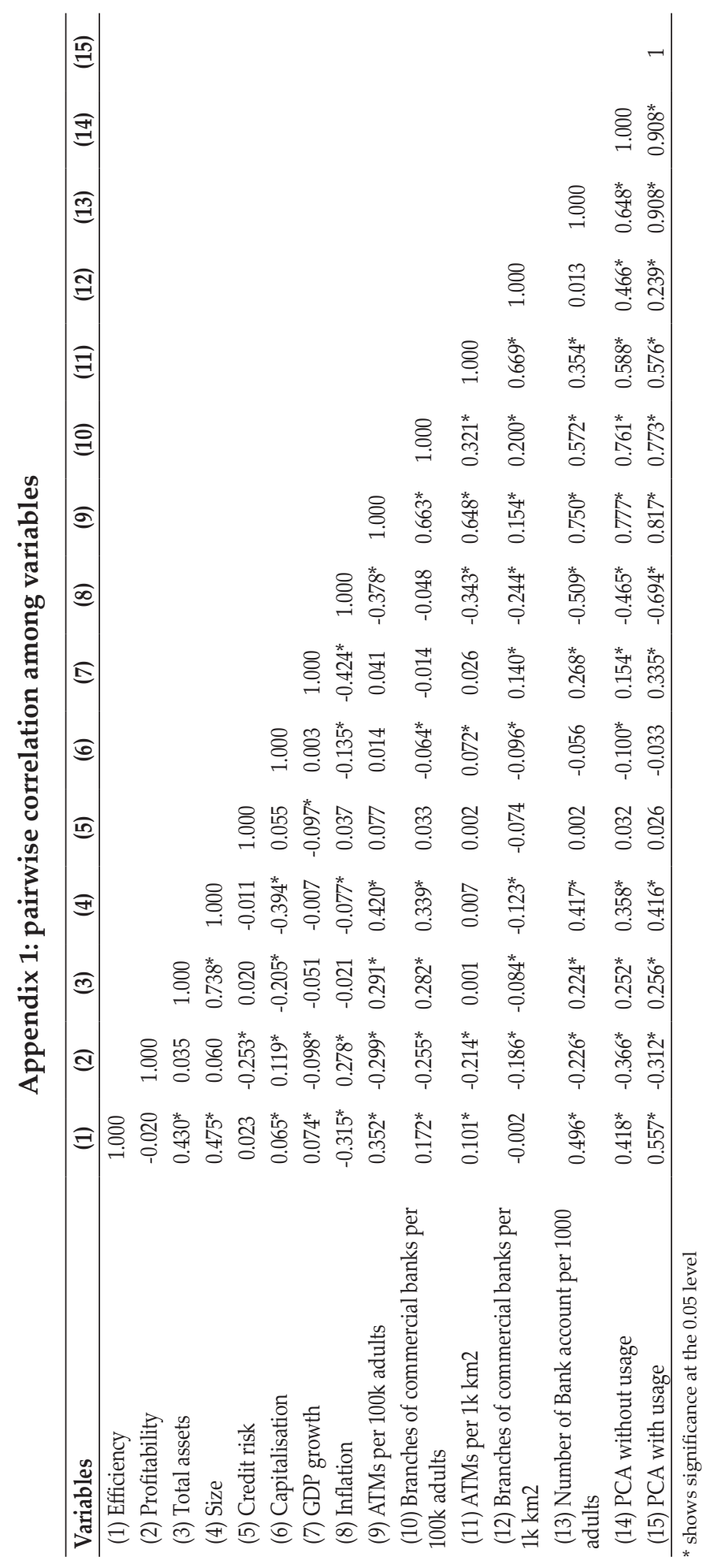


This page is intentionally left blank 